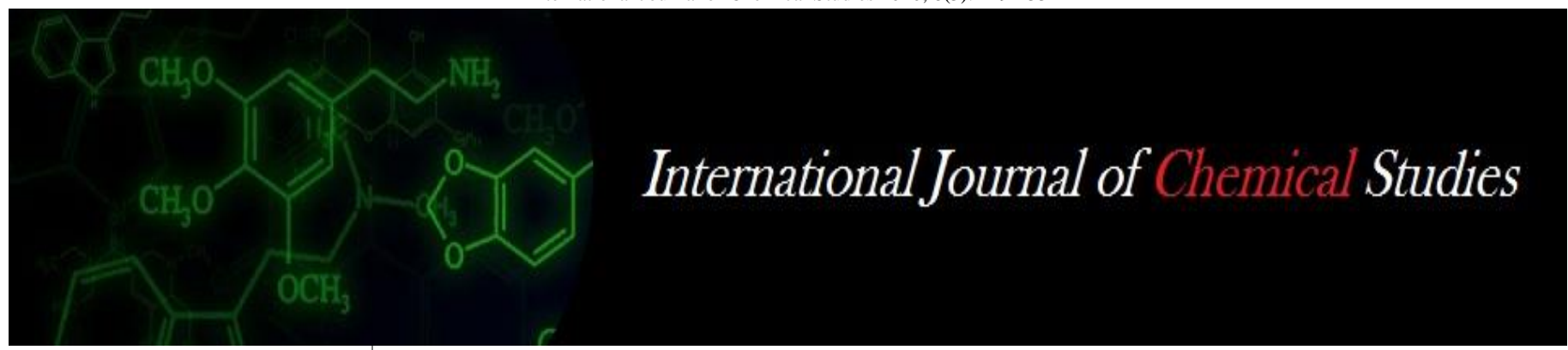

P-ISSN: 2349-8528

E-ISSN: 2321-4902

www.chemijournal.com

IJCS 2020; 8(3): 129-133

(C) 2020 IJCS

Received: 13-03-2020

Accepted: 15-04-2020

Jitendra Kumar

ICAR-IISS, Navibagh, Berasia

Road, Bhopal, Madhya Pradesh, India

\section{Nirmal De}

Institute of Agricultural Science, Banaras Hindu University,

Varanasi, Uttar Pradesh

\section{Pallab Sharma}

Bishwanth College of

Agriculture, Assam Agriculture

University, Assam, India

\section{A Pradhan}

S.G. College of Agriculture,

Jagdalpur, Indira Gandhi Krishi Vishwavidhalaya, Chhattisgarh, India

G Ravindra Charry

Project Coordinator AICRPDA, CRIDA, Hyderabad, Telangana, India
Corresponding Author:

Nirmal De

Institute of Agricultural Science,

Banaras Hindu University,

Varanasi, Uttar Pradesh

\section{Long term influence of tillage management on physical condition of soil under acidic soil of rainfed rice cropping system of Brahmpura valley of Assam}

\author{
Jitendra Kumar, Nirmal De, Pallab Sharma, A Pradhan and G Ravindra \\ Charry
}

DOI: https://doi.org/10.22271/chemi.2020.v8.i3b.9214

\begin{abstract}
The present study evaluated the effects of long-term tillage operation on soil physical properties and nutrient dynamics on surface soil. The soil samples were collected at 0 to $15 \mathrm{~cm}$ soil depth profiles in the year of 2016 and 2017 from following treatment (T1) Minimum Tillage, (T2) Minimum tillage with Two harrowing, (T3) Minimum tillage harrowing + Pulverization (T4) Conventional Tillage (T5) Farmers Practices (T6) Barren land The samples were analyzed for physical properties, Soil organic carbon and macronutrient. The statistical analysis was made in SAS 9.3 DMRT test was employed to compare the mean of estimated soil nutrient dynamics. Coupled with other physic chemical parameters of soil affected by different tillage treatment. The effect of tillage management was found significant on most of soil physic chemical parameters the result revealed that the minimum tillage had highest amount of available $\mathrm{N}, \mathrm{P}, \mathrm{K}$ and $\mathrm{S}$ over other tillage treatments. The highest SOC was found in minimum tillage where as lowest was recorded in farmers practice. The result also revealed that the physical condition of soil is significantly affected by the tillage management as a result the aggregation and water available capacity was found more in minimum tillage compare with the conventional and farmers practices. This study showed that minimum tillage enhances physical environment of soil as well as availability of nutrients that may result sustainable soil health and enhance crop yield.
\end{abstract}

Keywords: Minimum tillage, conservation tillage, water stable aggregate, soil organic carbon, macronutrient. barren land

\section{Introduction}

Holistic management of arable soil is the key to dealing with the most complex, dynamic, and interrelated soil properties, thereby maintaining sustainable agricultural production systems, the lone foundation of human civilization. Any management practice imposed on soil for altering the heterogenous body may result in generous or harmful outcomes (Derpsch et al 2010, Wolfarth et al 2011) ${ }^{[6,21]}$. Unsuitable management practices cause degradation in soil health (depletion of organic matter and other nutrients) as well as decline in crop productivity (Ramos et al 2011) ${ }^{[19]}$. Reducing disturbance of soil by reduced tillage influences several physically (Lopez-Garrido et al 2012) ${ }^{[14]}$, chemically (Page et al 1989) ${ }^{[17]}$, and biologically (Bronick et al 2005, Munoz et al 2007) ${ }^{[2,15]}$ interconnected properties of the natural body. Soil tillage is among the important factors affecting soil properties and crop yield. Among the crop production factors, tillage contributes up to $20 \%$ and affects the sustainable use of soil resources through its influence on soil properties. The judicious use of tillage practices overcomes edaphic constraints, whereas inopportune tillage may cause a variety of undesirable outcomes, for example, soil structure destruction, accelerated erosion, loss of organic matter and fertility, and disruption in cycles of water, organic carbon, and plant nutrient (Lal 1993) [13]. Reducing tillage positively influences several aspects of the soil whereas excessive and unnecessary tillage operations give rise to opposite phenomena that are harmful to soil. Therefore, currently there is a significant interest and emphasis on the shift from extreme tillage to conservation and no-tillage methods for the purpose of controlling erosion process 
(Iqbal 2005) ${ }^{[9]}$. Conventional tillage practices cause change in soil structure by modifying soil bulk density and soil moisture content. Therefore the present was planned to determine the effect of different tillage systems in on soil physical and nutrient status of in rainfed rice based cropping system under of Brahnputra valley region of Assam.

\section{Material and Method \\ Description of the experiment}

Field experiments were conducted at the Research Farm of Bishwanath College of Agriculture Bishwanath chariali, Assam Agricultural Univercity, Assam during Kharif season 2016 and 2017 under AICRP on Dry Land Agriculture the soil order of the site is inceptisol. it is situated in between $26.53-26.88^{\circ} \mathrm{N} \& 93.38-93.63^{\circ} \mathrm{E}$ with altitude ranging from $550-760 \mathrm{~m}$ above mean sea level. The area is under forest and natural vegetative cover and occurs on gently sloping subdued plateaus, as well as on upper and lower piedmonts with different physiographic settings.

Soil sampling and chemical analyses: Soil samples were collected from the top soil layer $(0-15 \mathrm{~cm})$ after harvest of the rice crop, and then were air dried and subsequently grounded to pass a $0.25 \mathrm{~mm}$ sieve. Available nitrogen content of soil was determined by alkaline permanganate method (Subbia and Asija, 1956).Available phosphorus (Olsen's method) by extraction with $\mathrm{NaHCO}_{3} \quad 0.5$ mol $\mathrm{L}^{-1}$ at $\mathrm{pH} \quad 8.5$ and spectrophotometric determination. Available potassium by extraction with ammonium acetate $1 \mathrm{~N} \mathrm{~L}^{-1}$ at $\mathrm{pH} 7$ and determination by flame photometer. Available sulphur content was determined by Turbidi metrically (Chesnin and Yien, 1950) [3]. Physical parameterslike Bulk density, Porosity, Water Stable aggregate mean weight diameter was estimated by standard protocol.

Statistical analysis: All ANOVA, regression, and multivariate analyses were conducted in SAS 9.3. Treatments were analyzed by one-way ANOVA and significant differences between means were judged by Turkey's post-hoc tests.

\section{Result and Discussion \\ Macronutrient dynamics}

The available $\mathrm{N}, \mathrm{P}, \mathrm{K}$ and $\mathrm{S}$ measured was significantly influenced $(P \leq 0.05)$ by different tillage practices (Table 1 , Fig. 1) on the surface soil $(0-15 \mathrm{~cm})$. The lowest average nitrogen content was found in the conventional tillage 209.07 $\mathrm{kg} \mathrm{ha}^{-1}$ and it was observed that with reducing the tillage operation resulted into increase amount of available $\mathrm{N}$ contents as a result the minimum tillage showed the highest available $\mathrm{N}$ content $\left(282.33 \mathrm{~kg} \mathrm{ha}^{-1}\right)$ among all the treatment. Similar results have been obtained by other workers. Iqbal et $a l$., (2010) working on the influence of tillage and farm yard manure reported higher $\mathrm{N}$ content under minimum tillage and lower $\mathrm{N}$ content under conventional tillage. Our finding was consistent with Havlin et al., $2005^{\text {[22] }}$ who reported tillage and fertilization can significantly affect the amount of available $\mathrm{N}$ in the soil.

Significant effect of tillage was also recorded in the potassium availability, it was followed the similar trend (Fig. 2) that was observed in the available Nitrogen. The highest phosphorus content $\left(19.54 \mathrm{~kg} \mathrm{ha}^{-1}\right)$ was found in minimum tillage which was significantly higher than the other tillage practices, followed by minimum tillage with two harrowing $(16.09 \mathrm{~kg}$ $\mathrm{ha}^{-1}$ ) followed by minimum tillage with a harrowing and pulverization (15.55 $\left.\mathrm{kg} \mathrm{ha}^{-1}\right)$ This showed that gradual increasing intercultural operation reflected in terms of decreasing phosphorous content. Lowest phosphorous was found in farmer's practices (11.67 $\left.\mathrm{kg} \mathrm{ha}^{-1}\right)$. Phosphorous content in conventional tillage is slightly more that the farmer's practices but both are statistically at par. In barren land the phosphorus content was more that the conventional tillage but less than minimum tillage reinforce the concept of disturbing soil by tillage resulted into decreased the availability of phosphorous. The highest sulphur $\left(21.43 \mathrm{~kg} \mathrm{ha}^{-}\right.$ $\left.{ }^{1}\right)$ content was found in Minimum tillage, with increasing the soil disturbances in terms of tillage and intercultural operations resulting increase the $\mathrm{S}$ content. The lowest $\mathrm{S}$ content 14.18 and $14.01 \mathrm{~kg} \mathrm{ha}^{-1}$ was recorded in conventional tillage and farmers practices respectively (Table.1 and Fig. 1).

\section{Soil Organic Carbon (SOC)}

Soil Organic carbon was also significantly influenced $(P \leq$ 0.05 ) by the different tillage practices (Table 2, Fig. 2) at our study sites. The highest SOC $\left(5.53 \mathrm{~g} \mathrm{~kg}^{-1}\right)$ was recorded in minimum tillage which was significantly higher than the other tillage practices. Hooker et al. (2005) also found that within a tillage treatment, residue management had little effect on SOC in the surface soil layer. Campbell et al. (1999) ${ }^{[4]}$ reported very small increases $\left(0-3 \mathrm{Mg} \mathrm{ha}^{-1}\right)$ in $\mathrm{C}$ storage under no-tillage in the $0-15 \mathrm{~cm}$ soil depth over an 11 years experiment. Several studies have shown that there is no significant increase in the overall mass of soil organic carbon (C). Inappropriate tilling deteriorates the soil structure and can promote soil erosion and deplete the soil nutrients and C stocks. On the basis of global data set, West and Post (2002) concluded that soil $\mathrm{C}$ sequestration was generally increased by no-tillage (NT) practices, but had a delayed response, with peaks in 5-10 years.

\section{Soil reaction (pH) and electrical conductivity (EC)}

Different tillage systems no significant $(P \leq 0.05)$ effect on $\mathrm{pH}$ (Table 1). $\mathrm{pH}$ of our study site was in acidic range, However the highest $\mathrm{pH}$ was recorded in minimum tillage with two harrowing and lowest was in the uncultivated land (Barren land) Our findings are consistent with found that fertilized NT soils develop lower $\mathrm{pH}$ values on the soil surface than tilled soils (Tarkalson et al., 2006) [23]

The effect of tillage was not significant over the treatment in EC, Moreover the highest EC was recorded in the minimum tillage in Bishwanth chari ali where as the lowest was recorded in the farmers practice vis-a-vis barren land this is with the findings of Qian et al (1994b) ${ }^{[18]}$ who reported that the opening and aeration of the top soil layers allowed increased leaching to occur in the surface soil.

\section{Physical properties of soil Bulk Density}

The Bulk density measured was significantly influenced $(P \leq$ $0.05)$ by different tillage practices at the $0-15 \mathrm{~cm}$ to. A comparison of tillage practices showed that bulk highest density was lowest $\left(1.36 \mathrm{Mgm}^{-3}\right)$ recorded in minimum tillage system and highest $\left(1.41 \mathrm{Mgm}^{-3}\right)$ recorded in farmers practice treatment, moreover the gradual increase in the intercultural operations and different tillage resulted into gradual increase in the BD the value of bulk density was increased gradually. The bulk density was ranged from lowest $\left(1.36 \mathrm{Mgm}^{-3}\right)$ recorded in minimum tillage system and highest $\left(1.41 \mathrm{Mgm}^{-3}\right)$ recorded in farmers practice as we are increasing the intensity of tillage disturbances the value of bulk density was increased 
gradually (table 2). The results are in line with the finding of Jat et al., $2006^{[10]}$. Therefore our finding reinforcing the fact that the gradual increase the disturbances in the soil by increased no of tillage and intercultural operations resulting more compaction of soil that leads to increase bulk density. The decrease in bulk density under tilled plots may be due to increase in non-capillary porosity and low soil mass per unit volume. Owing to the progressive increase in bulk density after tillage, the difference between the tilled and no tilled treatments becomes smaller and smaller with the time since tillage progresses. The No Tillage system maintained a significantly greater amount of residue on the soil surface increase soil organic carbon and biotic activity (Lal, 1989; Karlen et al 1994) ${ }^{[12]}$, thereby decreasing bulk density, particularly near the soil surface.

\section{Porosity}

The porosity measured was significantly influenced $(P \leq$ 0.05 ) by different tillage practices at the $0-15 \mathrm{~cm}$ in both the study sites. The effect of tillage practices (Table. 2) showed that the highest porosity was recorded in minimum tillage $(48.97 \%)$ system followed by minimum tillage with two additional harrowing (47.24\%) followed by minimum tillage with harrowing and pulverization followed and lowest was in conventional tillage $(47.01 \%)$ these both treatment slightly different values but statistically at par. It had been also reported that minimal and no tillage would decrease the soil porosity for aeration, but increase the capillary porosity; as a result, it enhances the water holding capacity (Fig.3) of soil along with bad aeration of soil (Glab and Kulig, 2008,) [7]. They reported that the porosity of soil with conventional tillage was significantly higher in comparison with reduced tillage.

\section{Available water Content}

Available water capacity was significantly (Table.2, Fig. 3) influenced $(P \leq 0.05)$ by the effect of tillage practices. The data revealed that highest AWC was recorded in minimum tillage (44.5\%) system followed by minimum tillage with two additional harrowing \& Pulverization (43.88\%) followed by barren land (43.78) followed by minimum tillage with harrowing $(43.33 \%)$ followed by conventional tillage and lowest was conventional tillage $(42.75 \%)$.Our result was in agreement with, (Gregorich et al., 2005) ${ }^{[8]}$, who was reported that increases of soil water content, had been observed under reduced and zero tillage system.

\section{Water Stable aggregate (WSA)}

Reduced tillage practices showing the higher WSA compare with the intensive tillage and more intercultural operations. The Water Stable aggregate (WSA) measured was significantly influenced $(P \leq 0.05)$ by different tillage practices (Table 2, Fig. 3) in our study sites the range of WSA was varied from 63.82 to $53.24 \%$. The highest WSA was recorded in minimum tillage system $(63.82 \%)$ followed by minimum tillage with two additional harrowing $(60.40 \%)$ further slight decrease was recorded with additional pulverization (59.22\%) and slightly less WSA was recorded in Barren land $(58 \%)$ whereas in conventional tillage and farmers practice there was a drastic decrease in WSA was recorded and both are statistically at par.. The same results were obtained by Hůla et al. (2010), who found that, after three years, the ploughing variant showed worsened soil structure in comparison to reduced tillage. Soil tillage based on ploughing can result in faster deterioration of soil structure compared to shallower tillage less disturbing the soil. According to various authors (Daraghmeh et al. 2009; Bogužas et al. 2010) ${ }^{[5,1]}$, site adaptable tillage, in comparison to conventional methods, increases the amount of water stable aggregates and improves (soil) structure due to a combination of greater amounts of organic matter, reduced bulk weight of soil, and a greater share of larger aggregates.

\section{Conclusion}

After long term tillage management years in the, different tillage practices showed that they influenced soil physical and chemical properties along with the improvement of SOC status in the soil profile and improved other soil properties, reduced the bulk density, increased porosity, AWC, and WSA. After four years, the chemical properties were also improved Minimum Tillage practices. The highest total $\mathrm{N}$ $(\%), \mathrm{P}, \mathrm{K}$, and $\mathrm{S}$ in their available forms were found in zero tillage. Therefore, minimum tillage (Reduced soil disturbance with was found to be suitable to improve soil conditions and sustained the soil productivity and health.

Table 1: Effect of different tillage management on $\mathrm{pH}, \mathrm{EC}$, Soil organic carbon and nutrient dynamics of soil.

\begin{tabular}{|c|c|c|c|c|c|c|c|}
\hline Treatments & $\mathbf{p H}$ & $\mathbf{E C ~ d s m}^{-1}$ & $\mathbf{S O C ~ g k g ~}^{\mathbf{1}}$ & $\mathbf{A N ~ K g h a}^{-1}$ & $\mathbf{A K ~ k g ~ h a - ~}^{\mathbf{1}}$ & AP Kgha $^{-1}$ & $\mathbf{A S ~ K g h a}^{-1}$ \\
\hline Minimum Tillage & 5.363 & 0.09 & 4.36 & 284.33 & 309.57 & 19.09 & 21.43 \\
\hline Two harrowing & 5.837 & 0.12 & 5.53 & 255.06 & 265.61 & 16.54 & 18.88 \\
\hline harrowing + Pulverization & 5.267 & 0.14 & 4.33 & 229.97 & 235.19 & 15.55 & 17.89 \\
\hline Conventional Tillage & 5.633 & 0.14 & 4.40 & 242.52 & 268.60 & 11.84 & 14.18 \\
\hline Farmers Practices & 5.420 & 0.10 & 3.33 & 209.07 & 244.30 & 11.67 & 14.01 \\
\hline Barren land & 5.153 & 0.09 & 4.88 & 221.61 & 241.26 & 14.40 & 16.74 \\
\hline LSD & 0.620 & 0.05 & 0.92 & 19.98 & 20.95 & 3.79 & 6.13 \\
\hline
\end{tabular}

Table 2: Effect of different tillage management on soil physical properties of soil

\begin{tabular}{|c|c|c|c|c|c|c|c|c|c|c|c|}
\hline Treatments & BD $\left(\mathbf{M g m}^{-3}\right)$ & Porosity (\%) & AWC (\%) & WSA (\%) & Sand (\%) & SE $( \pm)$ & Clay (\%) & SE $( \pm)$ & Silt (\%) & SE $( \pm)$ \\
\hline Minimum Tillage & 1.36 & 48.97 & 44.50 & 60.04 & 65.37 & 0.47 & 21.60 & 0.58 & 10.23 & 0.13 \\
\hline Two harrowing & 1.38 & 47.24 & 43.33 & 58.78 & 64.83 & 0.80 & 22.00 & 0.43 & 10.77 & 0.40 \\
\hline harrowing + Pulverization & 1.39 & 47.48 & 43.88 & 59.22 & 65.04 & 0.30 & 23.00 & 0.41 & 12.76 & 0.59 \\
\hline Conventional Tillage & 1.37 & 47.01 & 42.75 & 53.32 & 66.65 & 0.66 & 21.00 & 0.64 & 12.55 & 0.29 \\
\hline Farmers Practices & 1.41 & 46.69 & 41.60 & 63.82 & 67.60 & 0.17 & 19.60 & 0.10 & 12.60 & 0.20 \\
\hline Barren land & 1.39 & 47.47 & 43.78 & 53.24 & 69.82 & 0.55 & 21.80 & 0.48 & 11.18 & 0.21 \\
\hline LSD & 0.04 & 1.45 & 10.24 & 0.06 & & & & & & \\
\hline
\end{tabular}




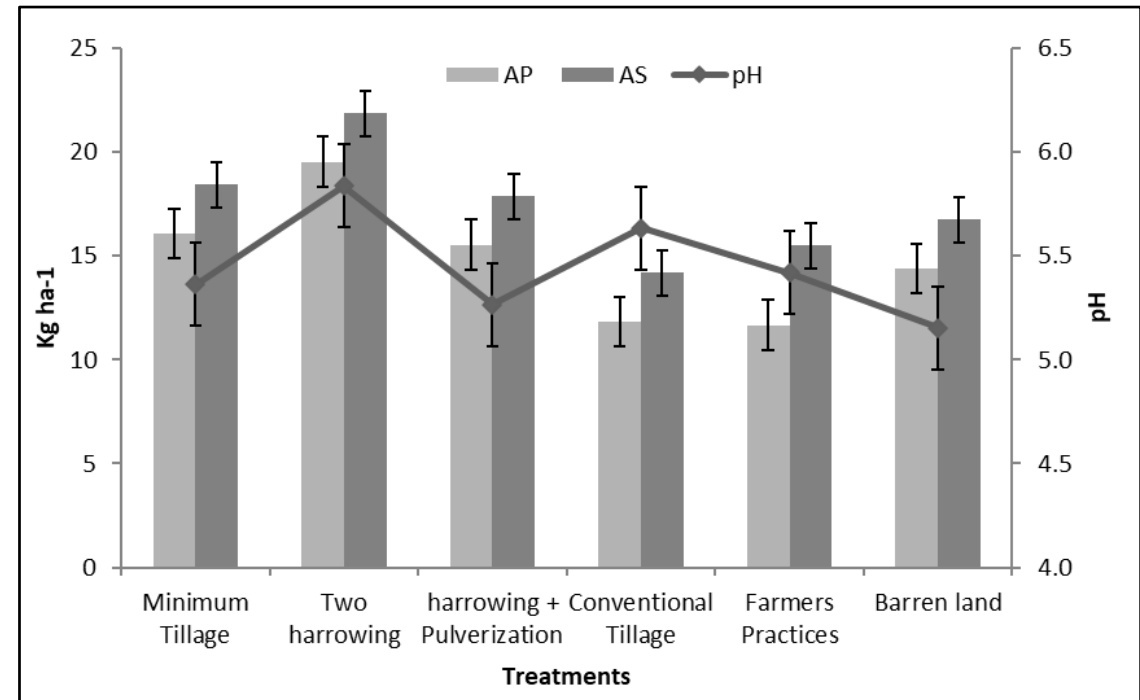

Fig 1: Influence of tillage management on available Phosphorous, Available $\mathrm{S}$ and $\mathrm{pH}$.

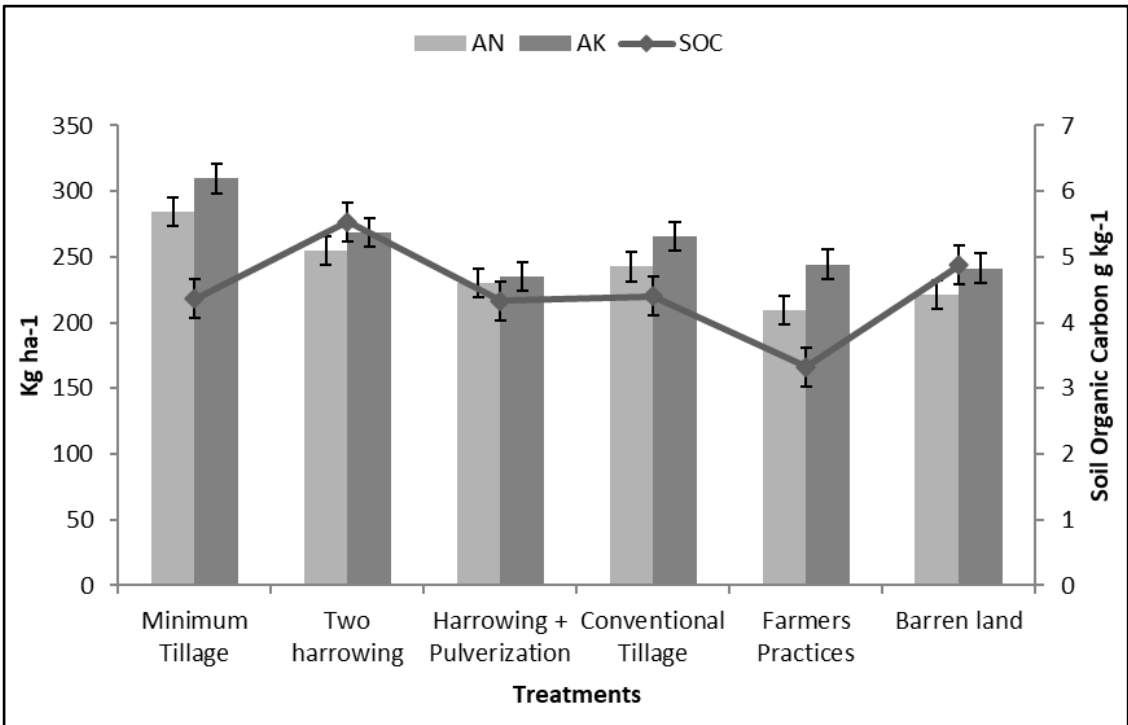

Fig 2: Influence of tillage management on Soil Organic Carbon and available nitrogen and available potassium at Bishwanath chariali.

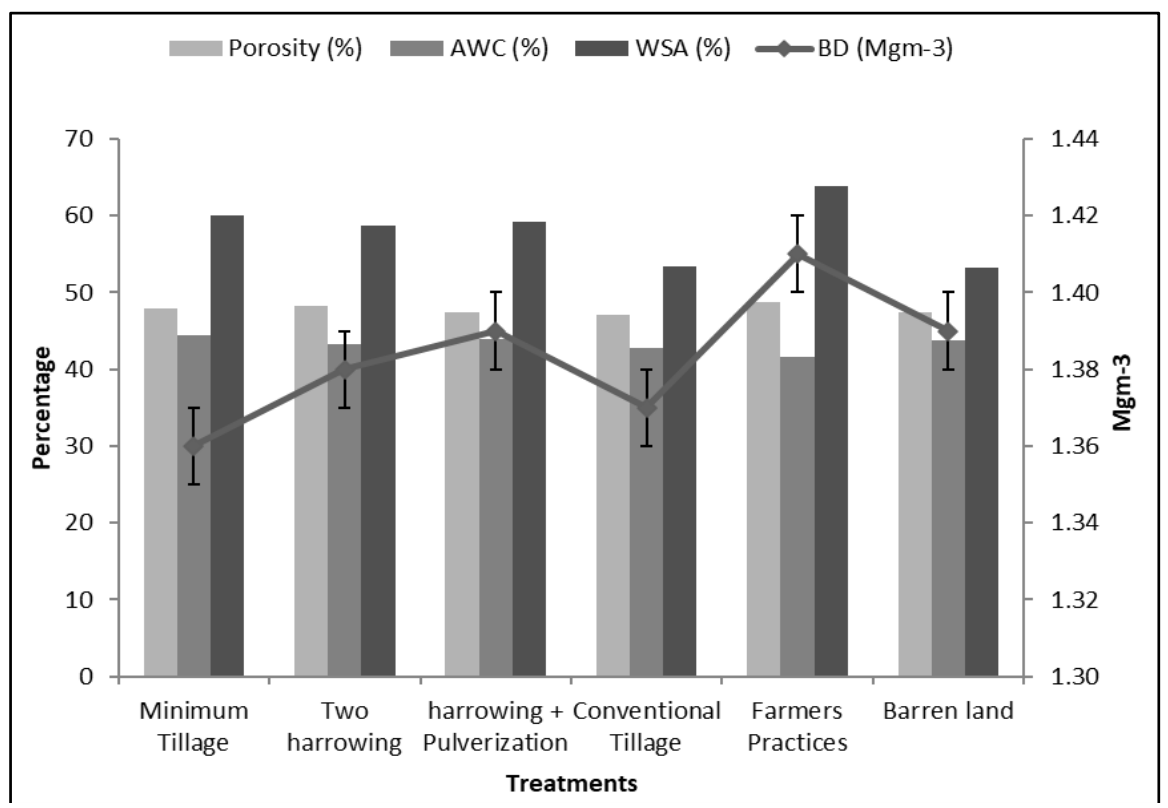

Fig 3: Influence of tillage management on bulk density, porosity, water stable aggregate and available water content of Soil

\section{References}

1. Bogužas V, Kairytė A, Jodaugienè D. Soil physical properties and earthworms as affected by soil tillage systems, straw and green manure management. Žemdirbystè - Agriculture. 2010; 97:3-14. 
2. Bronick CJ, Lal R. Soil structure and management: a review. Geoderma. 2005; 124(1, 2):3-22.

3. Chesnin L, Yein $\mathrm{CH}$. Turbidimetric determination of available sulphur. Soil Science Society of American Proceedings 1950; 15:149-151.

4. Campbell CA, Janzen HH, Juma NG. Case studies of soil quality in the Canadian prairies: Long-term field experiments. In: Soil Quality for Crop Production and Ecosystem Health (E.G. Gregorich and M.R. Cater, Eds.).351-397. Elsevier, Amsterdam, 1999.

5. Daraghmeh OA, Jensen JR, Petersen CT. Soil structure stability under conventional and reduced tillage in a sandy loam. Geoderma. 2009; 150:64-71.

6. Derpsch R, Friedrich T, Kassam A, Hongwen L. Current status of adoption of no-till farming in the world and some of its main benefits. International Journal of Agricultural and Biological Engineering. 2010; 1(3):1-25.

7. Glab T, Kulig B. Effect of mulch and tillage system on soil porosity under wheat (Triticum aestivum). Soil Till. Res. 2008; 99:169-178.

8. Gregorich EG, Rochette P, Vanden Bygaart AJ, Angers DA. Greenhouse gas contributions of agricultural soils and potential mitigation practices in Eastern Canada. Soil Tillage Res. 2005; 83:53-72.

9. Iqbal M, Hassan AU, Ali A, Rizwanullah M. Residual effect of tillage and farm manure on some soil physical properties and growth of wheat (Triticum aestivum L.). International Journal of Agriculture and Biology. 2005; 1, 54-57,

10. Jat ML, Gupta RK, Erenstein O, Ortiz R. Diversifying the intensive cereal cropping systems of the Indo-Ganges through horticulture. Chronica Horticulturae. 2006; 46(3):27-31.

11. Karlen DL, Wollenhaupt NC, Erbach DC, Berry EC, Swan JB, Eash NS et al. Long-term effects on soil quality. Soil and Tillage Research. 1994; 32:313-327.

12. Lal R. Conservation tillage for sustainable agriculture: tropics vs. temperate environments. Advances in Agronomy, 1989; 42:85-197.

13. Lal R. Tillage effects on soil degradation, soil resilience, soil quality, and sustainability. Soil and Tillage Research. 1993; 27(1, 4):1-8.

14. Lopez-Garrido R, Deurer M, Madej E, Murillo JM, Moreno F. Tillage influence on biophysical soil properties: the example of a long-term tillage experiment under Mediterranean rainfed conditions in South Spain. Soil and Tillage Research. 2012; 118:52-60,

15. Munoz A, opez-Pi ' neiro AL, Ram irez M. Soil quality attributes of conservation management regimes in a semiarid region of south western Spain. Soil and Tillage Research. 2007; 95(1, 2):255-265.

16. Olsen SR, Cole CV, Watanable FS, Dean LA. Estimation of available phosphorus in soils by extraction with sodium bicarbonate. USDA Circular, 1954, 939.

17. Page AL, Miller RH, Kuny DR. Methods of Soil Analysis. Part 2, American Society of Agronomy, Soil Science Society of America. Madison, Wis, USA, 2nd edition, 1989.

18. Qian PY, Wolt JD, Tyler DD. Soil solution composition as influenced by tillage and time of nitrogen-fertilization. Soil Sci. 1994b; 158:141-149.

19. Ramos ME, Robles AB, Sanchez-Navarro A, Gon- zalezRebollar JL. Soil responses to different management practices in rainfed orchards in semiarid environments. Soil and Tillage Research. 2011; 112(1):85-91,
20. Subbiah B, Asija GL. Alkaline permanganate method of available nitrogen determination. Current Sci. 1956; 25:259.

21. Wolfarth F, Schrader S, Oldenburg E, Weinert J, Brunotte J. Earthworms promote the reduction of Fusarium biomass and deoxynivalenol content in wheat straw under field conditions. Soil Biology and Biochemistry. 2011; 43(9):1858-1865.

22. Havlin JL, Beaton JD, Tisdale SL, Nelson WL. Soil Fertility and Fertilizers: An Introduction to Nutrient Management. 7th ed. Pearson Prentice Hall, Upper Saddle River, NJ, 2005.

23. Tarkalson DD, Payero JO, Hergert GW, Cassman KG. Acidification of soil in a dry land winter wheatsorghum/corn-fallow rotation in the semiarid US Great Plains. Plant Soil. 2006; 283:367-379.

24. West TO, Post WM. Soil Organic Carbon Sequestration Rates by Tillage and Crop Rotation SSSAJ. 2002; 66(6):1930-1946. 